\title{
ISLAMIC FINANCE IN SUSTAINABLE ECONOMY: EMPOWERMENT OF SUKUK WAKALAH TO BUILD WASTE INDUSTRY
}

\author{
Muhammad Zaid Farhand* \\ UIN Syarif Hidayatullah Jakarta, Tangerang Selatan, Banten \\ Putri Leli Nurjanah \\ UIN Syarif Hidayatullah Jakarta, Tangerang Selatan, Banten \\ Muhammad Nurcholis \\ UIN Syarif Hidayatullah Jakarta, Tangerang Selatan, Banten \\ Email: zfarhand7@gmail.com(correspondence author)
}

\begin{abstract}
The challenge that Indonesia faces in processing natural and nonbiological natural resources is the problem of waste management. High population figures, as well as increased incomes, affect consumption patterns that lead to increased waste generation in Indonesia. It is projected that in 2030 - 2050 waste production will increase, the problem of waste management in Indonesia can be seen from the following indicators, namely the high amount of waste generated, the level of waste management services is still low, limited number of final landfills, waste management institutions and cost problem. To overcome this problem, the issuance of wakalah sukuk as a source of funding for the waste industry center is a solution that can be done by the government. This research uses descriptive analysis research methodology with literature study data collection techniques. In the discussion explained about the concept of sustainable economy and wakalah state sukuk scheme in providing technology procurement financing to the waste processing industry. This research concluded that the wakalah state sukuk could be an alternative financing for technology procurement for the waste industry in increasing the effectiveness and efficiency of the company so that it is more environmentally sound and appropriate with SDG's.
\end{abstract}

Keywords: Sukuk wakalah, financing, waste processing industry 


\section{Introduction}

Geographically, Indonesia is located in Southeast Asia in the Malay Islands between the Indian Ocean and the Pacific Ocean. Indonesia has geographical coordinates of 6 ${ }^{\circ} \mathrm{N}-11^{\circ} 08^{\prime} \mathrm{LS}$ and from $95^{\circ}$ East - $141^{\circ} 45^{\prime} \mathrm{BT}$ which has a total land area of 1,922,570 $\mathrm{km}^{2}$, non-water land area of 1,829,570 km², watery land area of $93,000 \mathrm{~km}^{2}$, and sea area of $3,257,483 \mathrm{~km}^{2}$. Indonesia has around 17,504 islands (according to 2004 data) around 6,000 of which are not inhabited permanently, spread around the equator, and provide tropical weather (Lasabuda 2013).

Indonesia has a very high natural wealth. On the mainland, Indonesia has fertile land and is rich in minerals and abundant agriculture. In 2019 exports to the agricultural sector were USD 3,614.5 million (Ministry of Trade 2020). At sea, besides the potential for gas and petroleum, a large amount of vegetable and biological wealth is also owned. This can be seen from the volume of aquaculture production reaching 17.22 million tons in 2017 (Ministry of Maritime Affairs and Fisheries 2018). However, due to environmental problems, especially waste, the potential of the natural wealth is reduced. The Southeast Asia and Pacific Region produced 468 million tons of waste in 2016. On average this region produces an average of 0.56 kilograms per person per day (Fig.1). The biggest contributing countries for waste in this region are high-income countries or island nations (Kaza et al. 2018).

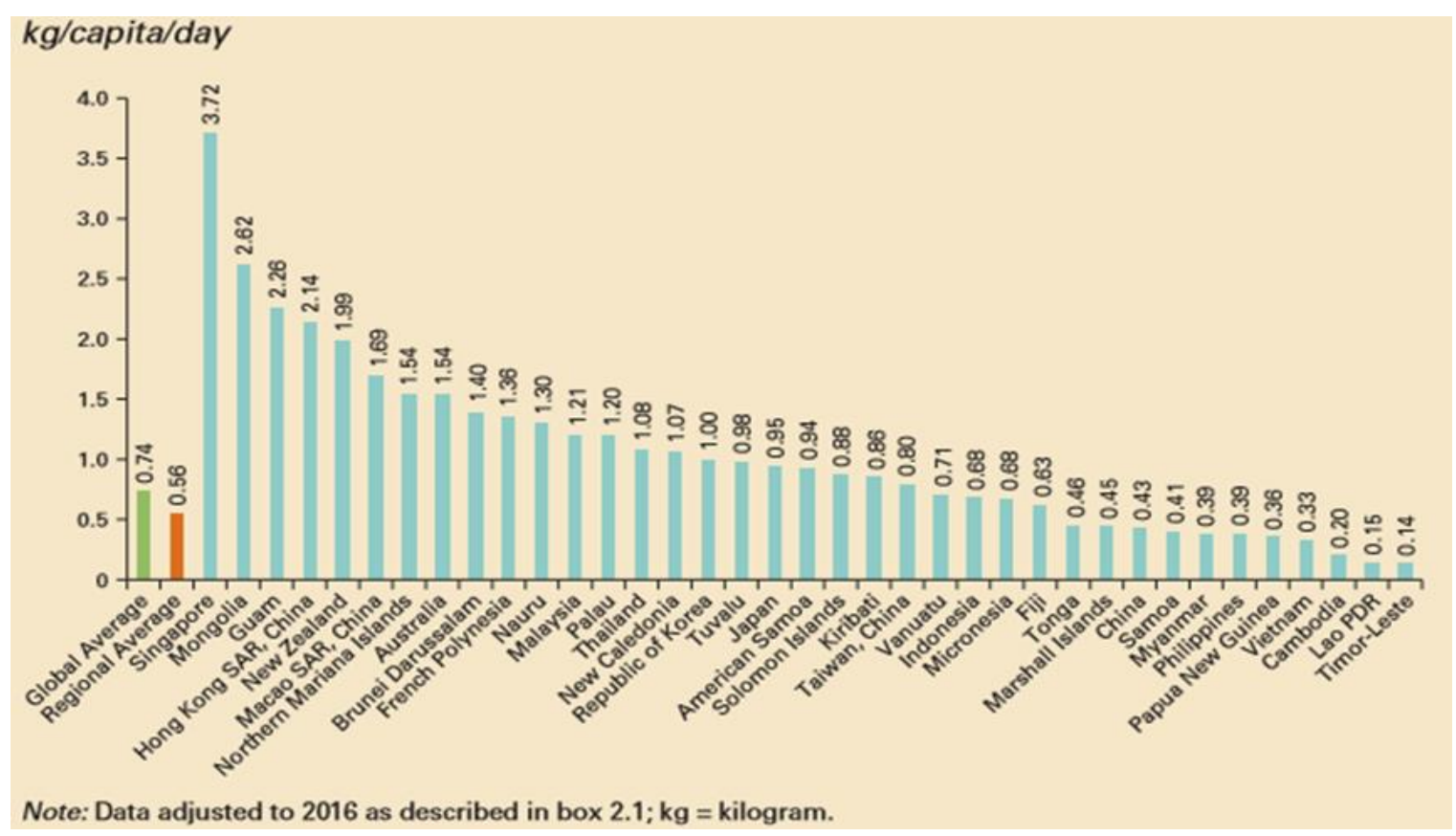

Figure1. Level of Waste Production: Southeast Asia and Pacific Region 
In 2016 the number of waste generation in Indonesia reached 65,200,000 tons per year with a population of 261,115,456 people. Indonesia's population projection shows the population continues to grow and will certainly increase the amount of waste generation. (Safitri, Purba, and Zulkifli 2018). Based on RI Law Number 18 Year 2008, one of the causes of the increase in the amount of waste is the increase in population and changes in the consumption patterns of the community, resulting in an increasingly diverse volume, type and characteristics of waste.

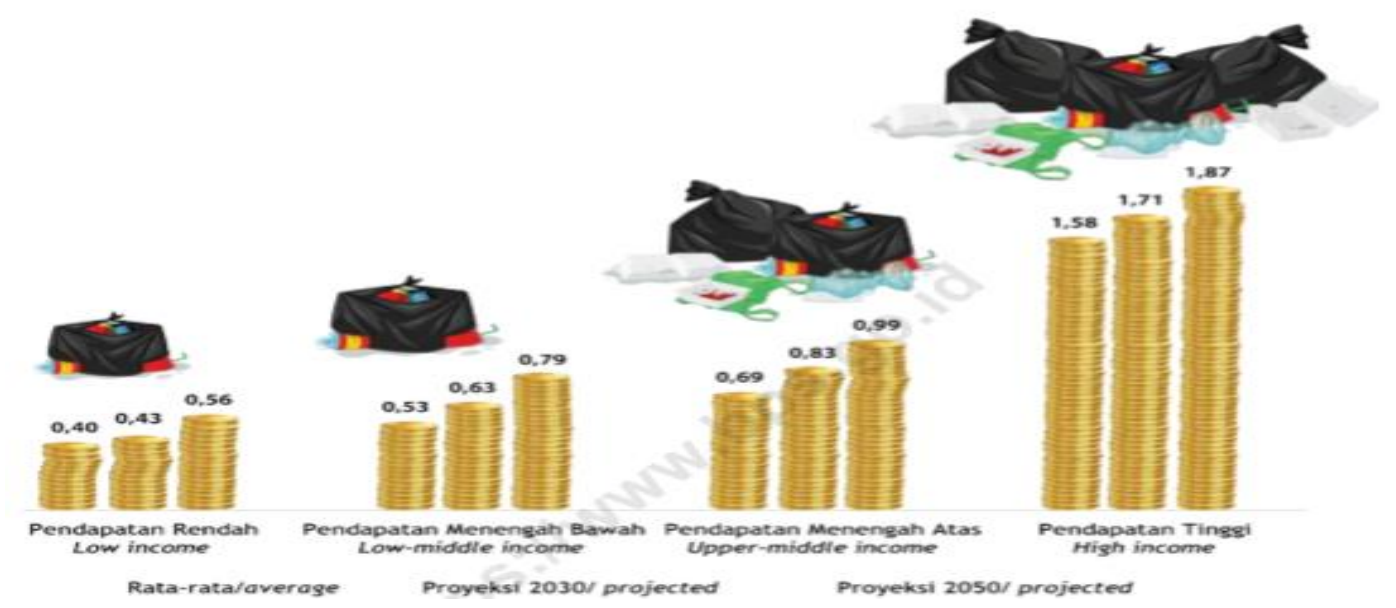

Figure2. Projected Per Capita Waste Increment According to Income Level, 2030 and 2050

It is projected that in 2030-2050 waste production will increase. Figure 2 explains the relationship between a country's income (GDP) with the level of waste production. A high level of income will cause changes in community consumption patterns to be higher and in the end there will be an increase in the generation of waste generated per person per day.

In several countries have tried to process waste in various ways. Starting from sorting garbage by providing a variety of specified waste disposal facilities such as Japan where the waste is not directly put into one bag, but rather separated from food waste, non-organic to goods that cannot be put into plastic waste such as air conditioners, televisions, until stove. Even better, Sweden uses advanced technology to process waste by burning it and turning it into steam so that it can be used for 950,000 household heat needs and 260,000 household electricity needs (Riani 2019).

Urban waste management in Indonesia becomes an actual problem along with the increasing rate of population growth which has an impact on the increasing amount of waste generated. Several studies have analyzed the causes of problems that occur in 
waste management in Indonesia. Some researchers analyzed the problems faced in waste management in Indonesia, including the lack of a firm legal basis, inadequate landfills, lack of effort in composting, and the lack of landfill management with the right system (Chaerul, Tanaka, and $\vee$ Shekdar 2007). The problem of waste management in Indonesia can be seen from the following indicators, namely the high amount of waste generated, the level of waste management services is still low, limited number of final landfills, waste management institutions and cost issues (Kardono 2007).

To maintain the stability of an industry, strong financing is needed. This has become one of the problems faced by the garbage industry players. The component of financing a municipal waste management system is ideally calculated based on; investment costs, operating and maintenance costs, management costs, costs for development as well as costs for counseling and community coaching (Damanhuri and Padmi 2010).

The solution that can be done to overcome the problem of financing the waste industry center is with government assistance through the issuance of sukuk wakalah. Sukuk wakalah is the issuance of sukuk to finance projects or business activities that are managed based on wakalah contracts, by appointing certain agents (representatives) to manage businesses on behalf of holders sukuk, i.e. investor representatives, invest funds that are entrusted by investors in various types of investments or only one type of investment (Trisilo 2014).

Sukuk has a fairly good prospect in terms of the development of Islamic financial institutions and the high demand for Islamic financial instruments, the sukuk wakalah structure used is a structure that has flexibility in the use of investment contracts and investment objects. The issuance of wakuk sukuk to finance the procurement of technology for the waste industry center has the aim of increasing the role of Islamic finance for a sustainable economy, because with the presence of a waste industry center it can minimize losses caused by pollution that occurs. But the government also needs to consider the burden to be borne. One of them is the object of financing, namely the processing technology of the waste industry center will become a state asset as long as the sukuk tenure has not yet fallen. During this time, the technology of the waste industry center will be the responsibility of the government, the costs are so large that it becomes a burden on the government. In addition, the issuance of state sukuk will increase the burden of government debt, thereby increasing the burden on the state budget. The government also needs to pay attention to possible losses such as the crucial waste problem, which is organic waste which is generally produced by household waste and has no economic value because it cannot be recycled. 
The aim of this research is to explain the state sukuk sukuk model to analyze the implications of sukuk with the Wakalah structure in financing the waste industry center. The research objective is to create a financing model for procurement of waste processing technology through the SBSN wakalah.

\section{Research Methodology}

The research method used in this study uses a qualitative approach. Lexy J. Moleong in his book that qualitative research methods are research that intends to understand the phenomena experienced by research subjects (Moleong 2007). For example behavior, perception, motivation, action, etc., holistically, and by way of description in the form of words and language, in a special natural context and by utilizing various natural methods. Meanwhile, according to Sugiyono, qualitative research methods are research used to investigate, discover, describe, and explain the quality or idiosyncrasy of social influence that cannot be explained, measured or illustrated through a quantitative approach (Sugiyono 2008). As a result it can be concluded that the qualitative approach is a research method that uses various words that are descriptive, use analysis, refer to data, utilize existing theories as supporting material, and produce a theory.

The data collection technique used in this research is literature study. According to Nazir, data collection techniques by conducting a study of reviewers of books, literature, records, and reports that have to do with the problem being solved (Nazir 2014). According to Sugiyono, library studies are related to theoretical studies and other references relating to values, culture and norms that develop in the social situation under study, besides library studies are very important in conducting research, this is because research will not be separated from scientific literature (Sugiyono 2008). This technique is used to obtain the basics and opinions in writing which are done by studying various literatures related to the problem under study.

The analytical method used is descriptive analysis, Sugiyono (2008) a descriptive statistical analysis method used to analyze data by describing or describing data that has been collected as it is without intending to make conclusions that apply to the general or generalization.

In addition to descriptive analysis, this study also uses a SWOT analysis (SWOT analysis), which includes efforts to recognize strengths, weaknesses, opportunities, and threats that determine company performance. External information about opportunities and threats can be obtained from many sources, including customers, government documents, suppliers, banks, partners in other companies. Many 
companies use the services of scanning agencies to obtain newspaper clippings, research on the internet, and analysis of relevant domestic and global trends (Daft 2010). SWOT analysis is the systematic identification of various factors to formulate a company's strategy. This analysis is based on logic that can maximize strengths and opportunities, but at the same time can minimize weaknesses and threats. The process of making strategic decisions is always related to the development of the company's mission, goals, strategies and policies. Thus, strategic planning must analyze the factors of the company's strategy (strengths, weaknesses, opportunities and threats) in the current conditions (Freddy 2006).

\section{Result And Discussion}

\subsection{Suistanable Economy}

Sustainable development has 3 main pillars namely social pillars or dimensions, economic pillars and environmental pillars. The social pillars which include equality, health, education, security, housing and population have developed rapidly, especially in the fields of health, education and population. Indonesia has seriously and systematically carried out the development of these aspects in order to develop Indonesia's human resources that healthy and tough. In the economic field, Indonesia has experienced quite high rates of economic growth. Since the 70s and 80s, Indonesia's growth has reached around 8 percent per year, the rate of economic growth in 1989 reaching 7.46 percent. Compared to the development of social and economic pillars, the environmental pillar still has some weaknesses / shortcomings. The first weakness / shortcoming is: not yet implemented the regulation and enforcement of environmental pollution properly. (Nasional 2014).

The application of environmental standards requires additional costs for economic actors, compared with costs that do not pay attention to waste management specified in the regulations. So companies choose not to apply or not fully implement good waste management; Moreover, there are no legal sanctions both civil and criminal that have been successfully imposed. Thus, the impact of their behavior on the environment has an influence on the environment around the place of business and the flow of water and air, so the impact is broad (Nasional 2014).

The concept of green economy is a relatively new concept, but this concept is the development of sustainable development that is environmentally sustainable. Green economy or commonly called green economy is an economic regime that increases human welfare and social equality, while reducing the risk of environmental damage significantly (Makmun 2011). 
The sustainable economic model in Hong Kong offers several things. First, the criteria for sustainable development must be non-dictatorial, decentralized, and compatible with a market economy. The emphasis is on contracts rather than the legislative or administrative. Second, the essence of segment cooperation is creating a win-win situation rather than a game of "integrated" rent seeking, which is likely to produce more value created. Third, the requirement for progress to occur implies that duplicative programs and policies need to be avoided, and innovation must be encouraged. Fourth, satisfying conditions for only two aspects of the three cooperation segments imply less stringent standards for incremental improvement, and thus make entrepreneurial efforts more likely. Finally, three segments of cooperation, if practiced together and increasing over time, can achieve most, if not all, principles in the Rio Declaration without leading to specific principles in the Declaration (Lai et al. 2006).

The essence of green economy is low carbon growth, resource efficiency, and social inclusivity which has implications for sustainable development, energy management green economy in the city and also green business. Green economy also aims to improve welfare and increase economic growth, green economy has one principle, namely the consumption of sustainable products and the production of unsustainable products. This then carries the $3 R$ jargon to reduce (Reduce), reuse (Reuse), and recycle (Recycle) (Fauzia 2016).

Waste management into useful materials can provide benefits in increasing production efficiency and economic benefits for waste processing, reducing the cost of transportation to landfill and final disposal costs, saving natural resources and energy. Currently, garbage banks are scattered in various villages so that the goal of reducing the volume of waste and creating a small recycling industry that can be managed by the community and local government has been realized (Hasanah 2014).

From a study conducted by Latuconsina and Rusydi in 2017 regarding the estimated selling value of the waste component in the TPA Tamangapa, if calculated against the minimum wage value of Rp.850,000 / month, the economic value of dry waste is Rp. $86,050,000$ / day, or Rp.2,6 billion / month, can support 3000 workers (Latuconsina and Rusydi 2017). If wet waste is processed into compost, a total revenue of Rp. 161,275,000 / day or Rp. 4.8 billion / month. This revenue value is able to support 6000 people.

\subsection{Wakalah State Sukuk Scheme}

The basic structure of Wakalah Negara Sukuk can be illustrated as in Figure 3 below 


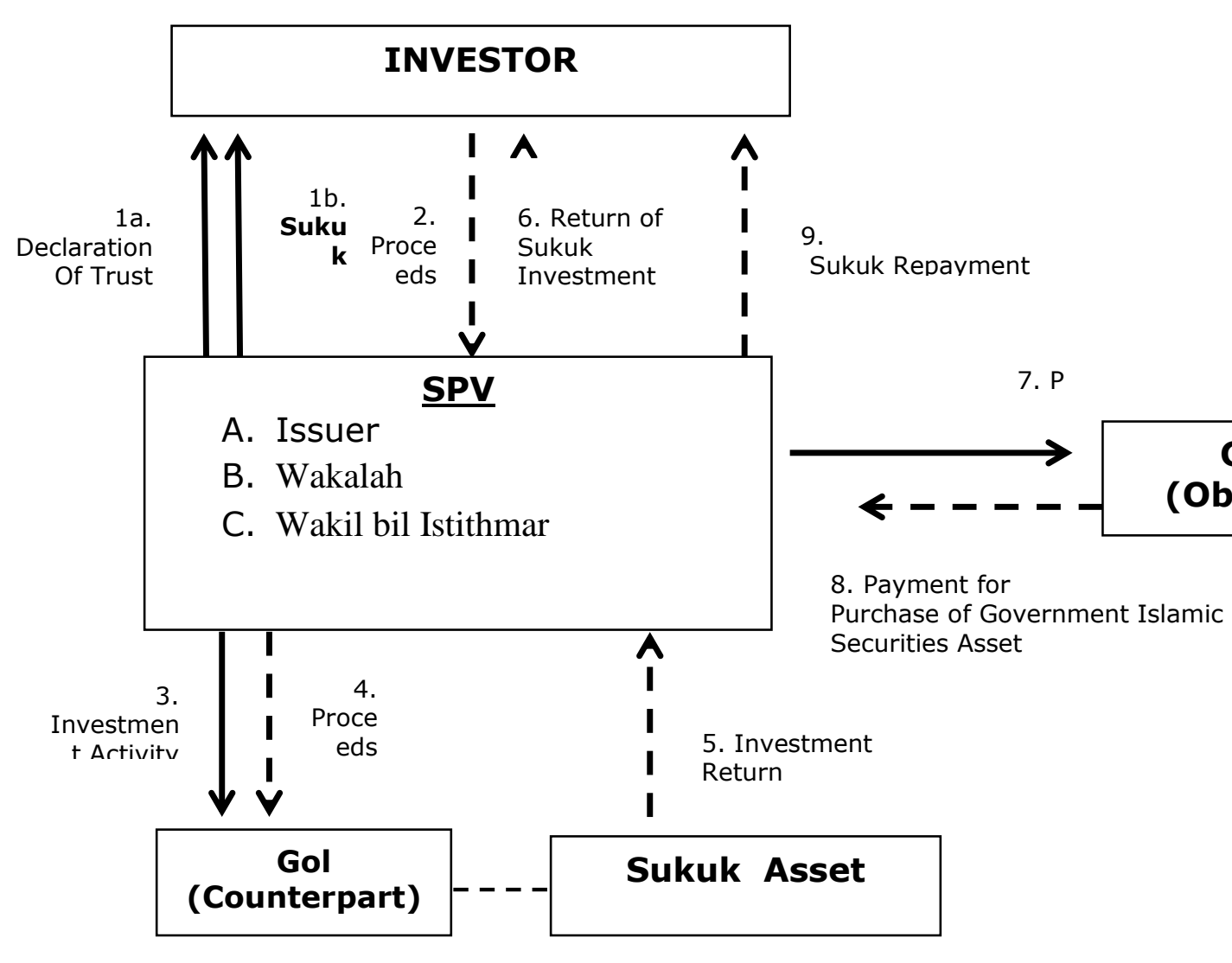

Source: (Direktorat Pembiayaan Syariah 2015)

Publishing

1. Wakalah State Sukuk issuing company declares itself to act as a Representative of the Sukuk holders, to manage the proceeds from the issuance of sukuk in the context of profit-making activities.

a. Sukuk issuing companies convey to prospective investors about the planned use of funds in various activities to be carried out;

b. Wakak contract used: wa bil bil ujrah or wakal bi dunil ujrah;

c. Sukuk issuing companies inform investment activities carried out, including: types of activities, composition of activities, calculation of profits for each activity, and composite calculations;

d. In the event that sukuk will be traded on the secondary market, the sukuk issuing company maintains a composition of funds using a minimum of $51 \%$ in tangible assets.

1b Sukuk issuance by sukuk issuing companies.

2. Proceeds from the issuance of sukuk (proceeds).

3. Sukuk issuing companies carry out various beneficial activities, in the form of ijarah, pilgrimage, and other activities that are in accordance with sharia principles, with the government as a counterpart. 
4. Investment activity funds.

\section{Payment of Rewards}

5. Profits derived from the results of these activities will be given to sukuk holders in return. Sukuk rewards can be given during the period of the sukuk periodically and / or at maturity according to the agreement.

6. Periodic payment of sukuk fees to sukuk holders

\section{Due Date}

7. At maturity, the government purchases sukuk assets by paying the price according to the agreement.

8. Price of payment for sukuk asset purchase.

9. Settlement of sukuk.

In the context of the issuance of a state sukuk sukuk, the sukuk issuing company stated that it acts as a trustee / representative of the sukuk holders to manage the proceeds from the issuance of sukuk in various profitable activities. As a representative, sukuk issuing companies conveyed to prospective investors about plans to use funds in various activities to be carried out, including plans for types of activities, planned composition of activities, estimated profits of each activity, and estimated composite profits. The wakalah contract to be used can be in the form of wakalah without ujrah (wakalah bi dunil ujrah) or wakalah with ujrah (wakalah bil ujrah).

Subsequently, the sukuk issuer company issued sukuk to investors with a nominal value of the issuance which was equivalent to the planned activities to be carried out. Proceeds from issuance (proceeds) are then managed by the sukuk issuing company to be invested in various activities that generate profits. In the case of sukuk issued with the aim to be traded on the secondary market (tradable), the sukuk issuing company will maintain the composition of activities of at least $51 \%$ in the form of tangible assets.

Sukuk rewards are profits derived from investment activities carried out by sukuk issuing companies. Rewards can be given to sukuk holders during the period of the sukuk periodically and / or at maturity according to the agreement and in accordance with the type of profit generated.

At maturity, through a new agreement, the government will buy back the sukuk wakalah assets from investors at an agreed price. The purchase is based on a promise of a buyer undertaking by the government, and a promise of a sale undertaking by the SPV. The purchase price of assets is equivalent to the nominal value of the state sukuk. Payment funds for these purchases will then be paid to investors as a payment of sukuk (Direktorat Pembiayaan Syariah 2015). 


\subsection{SWOT Analysis}

The initiation of state sukuk sukuk for the procurement of technology for the waste industry has several advantages, weaknesses, opportunities and challenges going forward. Through this SWOT analysis some aspects of empowerment of the sukuk state sukuk were formulated and alternative strategies to deal with these aspects were also formulated.

\section{Strength}

In this aspect, it contains all aspects of excellence for the government as the publisher of the state sukuk, and the executor of the funding activities for the waste industry center technology, namely:

a. Diversification of funding for the waste processing industry (Al-Husana 2017) A state sukuk with a wakalah structure can be an alternative funding / financing diversification in the procurement of waste industry technology where the source of funding is unlimited and managed transparently. And it is expected that the procurement of advanced technology will make the waste industry run effectively and efficiently and eliminate risks to the economy caused by waste.

b. Effectiveness and efficiency With the holding of technology for waste industry companies can provide effectiveness and efficiency because of their increased productivity and minimize environmental pollution.

c. Environmental and economic improvement (Astuti, Wahyu, and Andi 2011) With this sophisticated technology the company can improve the polluted environment and provide a better environmental impact.

d. Strengthening Islamic finance in the sustainable economic sector Through the issuance of a structured state sukuk sukuk financing for technology procurement for the waste industry center can play an active role in the welfare program.

\section{Opportunity}

This aspect contains all the elements that benefit or become a future opportunity for Indonesia with the financing of the wakalah sukuk processing technology, namely:

a. Very large infrastructure needs (Hariyanto 2016)

The issuance of a state sukuk with a wakalah structure will be one of the main sources for future infrastructure financing because the opportunities are enormous. In addition, state sukuk can also provide wider fiscal space to allocate sources of revenue.

b. Policy support (Hariyanto 2016) 
Through the support of the policy Law No. 192008 SBSN, became the main foundation of the government to use State Property (BMN) as the underlying assets and finance infrastructure development through sukuk, so as to encourage infrastructure acceleration in accordance with the master plan to accelerate the expansion of Indonesia's economic development.

c. Great sukuk potential and enthusiasm (Fatah 2011)

Investment instrument sukuk which provides investment opportunities that provide opportunities for Muslim and non-Muslim investors to invest in Indonesia so that sukuk can be utilized to build a nation's market economy is very responsive to sukuk almost all sukuk issued are completely absorbed by the market and can even lead to excess demand.

d. Good Sukuk Development (Reuters 2018)

In the period 2010-2014 sukuk experienced a fairly good development with an increase of $20 \%$. Better than bond growth of $7 \%$ from the same year.

\section{Weakness}

This aspect contains all aspects that become a burden or loss for the government as the issuer of the state sukuk as a financing for the procurement of waste processing technology for the waste industry center, namely:

a. Being a burden on the state budget (Astuti, Wahyu, and Andi 2011)

The holding of this waste processing technology financing means giving an additional burden to the government as long as the sukuk contract is to expire.

b. Large Needs of State Property (BMN) (Al-Husana 2017)

In the DSN-MUI fatwa it was stated that the minimum BMN requirement used for underlying assets was $51 \%$. These requirements are to fulfill the sale and purchase of sukuk in the secondary market. During this time, BMN agreed to provide land and building assets for underlying assets can be a burden on the government.

\section{Threats}

This cluster contains all aspects that pose risks or challenges in the future for the government as the publisher of the state sukuk as a financing for the procurement of waste processing technology for the waste industry centers, namely:

a. Risk of economic stability (Astuti, Wahyu, and Andi 2011)

With the current global economic conditions that are uncertain due to trade wars can be less profitable for the government to hold such waste processing technology because prices can soar up. 
b. Operational risk (Irham 2010)

Operational risk is a risk that generally originates from internal company problems, where this risk occurs due to the weak management control system (management control system) carried out by the company's internal parties.

c. Moral hazard (Legawa 2015)

Legawa stated that fraud that can occur at the planning stage in construction design that does not reflect field conditions, procurement plans and Self Estimated Prices (HPS) are inflated, and procurement plans that are not in accordance with the request of prospective users. This should be considered by the government in initiating the state sukuk in the provision of waste processing technology for the waste industry.

Table 1. SWOT Analysis Matrix Wakuk Wakalah for Procurement of Technology in the Waste Industry

\begin{tabular}{|c|c|c|}
\hline $\begin{array}{c}\text { ANALISIS } \\
\text { SWOT }\end{array}$ & STRENGTH & WEAKNESS \\
\hline OPPORTUNITY & $\begin{array}{l}\text { Kolaborasi fix asset } \\
\text { untuk memperbesar } \\
\text { pengolahan sampah. }\end{array}$ & $\begin{array}{l}\text { - Memproteksi barang } \\
\text { yang ditangguhkan } \\
\text { dengan asuransi agar } \\
\text { menjadi terjamin dari } \\
\text { kerusakan yang tidak } \\
\text { diinginkan. }\end{array}$ \\
\hline THREAT & $\begin{array}{l}\text { - Pendampingan pelaku } \\
\text { industri dalam } \\
\text { mengoperasikan dan } \\
\text { merawat teknologi. }\end{array}$ & $\begin{array}{l}\text { - Harmonisasi aturan } \\
\text { dan kebijakan untuk } \\
\text { mendukung } \\
\text { pembiayaan sukuk } \\
\text { pada ekonomi } \\
\text { berkelanjutan. }\end{array}$ \\
\hline
\end{tabular}

\subsection{Alternative Strategy}

\section{Strength X Opportunity}

Fix asset collaboration must be carried out by relevant stakeholders. This is useful to enlarge the scale of waste processing production. With the provision of waste processing technology as an asset funded by the state through SBSN with assets available by the industry in the form of land and buildings can make the production 
activities of the waste industry become more effective and efficient. That way profits will be more easily obtained while providing environmental sustainability.

\section{Strength $X$ Threat}

Assistance of business or industrial actors in operating and maintaining technology in order to minimize damage to machinery and human errors that occur during the implementation period. By conducting seminars, workshops and mentoring, it will improve the skills of industry players and increase effectiveness in the use of these technologies.

\section{Weakness X Opportunity}

Protect items that are deferred with insurance to be guaranteed against unwanted damage. Both the time before, during or even after a period of delivery of goods from the trustee to the industry or from suppliers to the trustee even when the use of the technology there is a possibility of damage to the goods due to accidents or other unexpected things. Therefore it is important for the government to provide insurance or guarantees for industry players so that the technology can be guaranteed from damage or other things that can harm the company or even other parties.

\section{Weakness $X$ Threat}

Harmonization of rules and policies needs to be done to provide a strong legal basis for this sukuk. This is because in order to synchronize the policies of the central government and the waste industry. Doing so along with proper supervision will create a strong synergy so that the rules and implementation can work properly.

\section{CONCLUSIONS AND RECOMMENDATIONS}

The level of environmental pollution that occurs is getting worse from year to year. Starting from wasteful human behavior to less optimal companies or industries in managing existing waste. Indonesia, as described by the World Bank, has a fairly bad rate of waste generation per capita, and it can increase for years to come if there is no innovation.

Technology is needed to improve the effectiveness and efficiency of waste treatment in order to minimize the impact of the existing waste generation. Some countries have tried to use waste to become something more valuable. An example is Sweden which uses waste by burning it and turning it into steam to meet the heat needs of 950,000 households and 260,000 household electricity needs in the country.

By empowering the sukuk sukuk state to finance the procurement of technology, it can improve the effectiveness and efficiency of the waste processing industry. Not only in terms of the economy that will improve in the long term such as the opening of jobs 
and improvements in product quality, but in terms of the environment and social have a great influence also for the sustainability of quality resources for Indonesia. For this reason, optimizing sukuk waqf is important.

\section{REFERENCE}

[1] Al-Husana, Rizqiyyah. 2017. "Islamic Finance for Blve Economy: Initiating Wakala SUkUk for Fishery Fleet." In FREKS OJK.

[2] Astuti, Umi Pudji, Wibawa Wahyu, and Ishak Andi. 2011. "Faktor Yang Mempengaruhi Alih Fungsi Lahan Pangan Menjadi Kelapa Sawit Di Bengkulu: Kasus Petani Di Desa Kungkai Baru (Factors Affecting the Conversion of Food Land into Palm Oil in Bengkulu: The Case of Farmers in Kungkai Baru Village)."

[3] Chaerul, Mochammad, Masaru Tanaka, and Ashok V Shekdar. 2007. "Municipal Solid Waste Management in Indonesia: Status and the Strategic Actions."

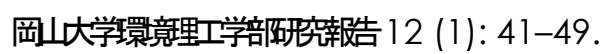

[4] Daft, Richard L. 2010. "Era Baru Manajemen Buku 2 Edisi 9 (A New Era of Management, Book 2, Issue 9)." Diterjemahkan Oleh Tita Maria Kanita, Jakarta: Penerbit Salemba Empat.

[5] Damanhuri, Enri, and Tri Padmi. 2010. "Pengelolaan Sampah (Waste Management)." Diktat Kuliah TL 3104: 5-10.

[6] Direktorat Pembiayaan Syariah, DJPPR Kemenkeu RI. 2015. "Sukuk Negara: Instrumen Keuangan Berbasis Syariah (State Sukuk: Sharia Based Financial Instruments)." Jakarta.

[7] Fatah, Dede Afdul. 2011. "Perkembangan Obligasi Syariah (Sukuk) Di Indonesia: Analisis Peluang Dan Tantangan (Development of Islamic Bonds (SUkUk) in Indonesia: Analysis of Opportunities and Challenges)." AL-'ADALAH 10 (1): 35-46.

[8] Fauzia, Ika Yunia. 2016. "Urgensi Implementasi Green Economy Perspektif Pendekatan Dharuriyah Dalam Maqashid Al-Shariah (The Urgency of Implementing Green Economy Perspective on the Dharuriyah Approach in Maqashid AlShariah)." Jurnal Ekonomi Dan Bisnis Islam (JEBIS) 2 (1): 87-104.

[9] Freddy, Rangkuti. 2006. "Analisis SWOT Teknik Membedah Kasus Bisnis (SWOT Analysis - Techniques for Dissecting Business Cases)." Jakarta: PT. Gramedia Pustaka Utama.

[10] Hariyanto, Eri. 2016. "Peluang Pembiayaan Infrastruktur Melalui Sukuk Negara (Opportunities for Infrastructure Financing through State Sukuk)." Artikel Oleh Pegawai Direktorat Jenderal Pengelolaan Utang Kementerian Keuangan.

[11] Hasanah, Uswatun. 2014. "Efektivitas Penggunaan Sistem Manajemen Sampah 
Perkotaan Di TPST (Tempat Pembuangan Sampah Terakhir) Kota-Kota Besar Indonesia (The Effectiveness of Using the Urban Waste Management System in TPST (Final Waste Disposal Sites) of Indonesian Big Cities)." Universitas Muhammadiyah Yogyakarta.

[12] Irham, Fahmi. 2010. "Manajemen Risiko, Teori (Risk Management, Theory)." Kasus Dan Solusi, ALFABETA, Bandung.

[13] Kardono, K. 2007. "Integrated Solid Waste Management in Indonesia." In Proc. International Symposium on EcoTopia Science 2007, 629-33.

[14] Kaza, Silpa, Lisa Yao, Perinaz Bhada-Tata, and Frank Van Woerden. 2018. What a Waste 2.0: A Global Snapshot of Solid Waste Management to 2050. The World Bank.

[15] Lai, Lawrence W C, Daniel C W Ho, Lawrence Wai Chung Lai, Kwong Wing Chau, Daniel Chi Wing Ho, and Frank T Lorne. 2006. "A 'Hong Kong' Model of Sustainable Development." Property Management.

[16] Lasabuda, Ridwan. 2013. "Pembangunan Wilayah Pesisir Dan Lautan Dalam Perspektif Negara Kepulauan Republik Indonesia (Development of Coastal and Ocean Areas in the Perspective of the Republic of Indonesia)." Jurnal IImiah Platax 1 (2): 92-101.

[17] Latuconsina, Muh Mansyursyah, and Bahrul Ulum Rusydi. 2017. "POTENSI EKONOMI MELALUI PENGOLAHAN SAMPAH DALAM PERSPEKTIF ISLAM (ECONOMIC POTENTIALS THROUGH SOLID WASTE TREATMENT IN ISLAMIC PERSPECTIVE)." Jurnal Iqtisaduna 3 (2): 187-204.

[18] Legawa, Panggih. 2015. "ANALISIS PERANAN INSPEKTORAT DAERAH DALAM PENCEGAHAN DAN PENDETEKSIAN FRAUD PENGADAAN BARANG/JASA PEMERINTAH DAERAH (STUDI KASUS PADA INSPEKTORAT DAERAH KABUPATEN KULON PROGO)." Universitas Gadjah Mada.

[19] Makmun, Makmun. 2011. "Green Economy: Konsep, Implementasi Dan Peran Kementerian Kevangan (Green Economy: Concept, Implementation and Role of the Ministry of Finance)." Jurnal Ekonomi Dan Pembangunan 19 (2): 1-15.

[20] Ministry of Maritime Affairs and Fisheries, Kementerian Kelautan dan Perikanan Republik Indonesia. 2018. "Laporan Tahunan Kementerian Kelautan Dan Perikanan Republik Indonesia Tahun 2017 (Annual Report of the Ministry of Maritime Affairs and Fisheries of the Republic of Indonesia 2017)." Jakarta.

[21] Ministry of Trade, Kementerian Perdagangan. 2020. "Perkembangan Ekspor NonMigas Sektoral (Growth of Sectoral Non-Oil and Gas Exports)." Jakarta. https://statistik.kemendag.go.id/growth-of-non-oil-and-gas-export-sectoral.

[22] Moleong, Lexy J. 2007. "Metodologi Penelitian Kualitatif Edisi Revisi (Qualitative 
Research Methodology, Revised Edition)." Bandung: PT Remaja Rosdakarya 103.

[23] Nasional, Badan Perencanaan Pembangunan. 2014. "Kajian Strategi Pengelolaan Perikanan Berkelanjutan (Review of Sustainable Fisheries Management Strategies)." Jakarta (ID): Bappenas.

[24] Nazir, Moh. 2014. "Metode Penelitian Cet. 9 (Research Methods Cet. 9)." Penerbit Ghalia Indonesia. Bogor.

[25] Reuters, Thomson. 2018. "Islamic Finance Development Report 2018: Building Momentum." ICD-Thomson Reuters.

[26] Riani, Asnida. 2019. "Cerita Akhir Pekan: 6 Negara Dengan Pengelolaan Sampah Terbaik, Apakah Ada Indonesia? (Weekend Story: 6 Countries with the Best Waste Management, Is There Indonesia?)," 2019. Liputan6.com.

[27] Safitri, P Ajeng, W Sartika Purba, and M Zulkifli. 2018. "Statistik Lingkungan Hidup Indonesia 2018-Pengelolaan Sampah Di Indonesia (Indonesia Environmental Statistics 2018-Waste Management in Indonesia)." BPS-Subdirektorat Stat. Lingkung. Hidup, 1-43.

[28] Sugiyono. 2008. Metode Penelitian Pendidikan:(Pendekatan Kuantitatif, Kualitatif Dan R \& D) (Educational Research Methods: (Quantitative, Qualitative and R\&D Approaches)). Alfabeta.

[29] Trisilo, Rudi Bambang. 2014. "Penerapan Akad Pada Obligasi Syariah Dan Sukuk Negara (Surat Berharga Syariah Negara/SBSN) (Application of Contracts for Sharia Bonds and Government Sukuk (Government Sharia Securities / SBSN))." Economic: Jurnal Ekonomi Dan Hukum Islam 4 (1). 